\title{
Viral respiratory tract infection and exacerbations of asthma in adult patients
}

\author{
R BEASLEY, E D COLEMAN, Y HERMON, P E HOLST, T V O'DONNELL, M TOBIAS \\ From the Department of Medicine, Wellington School of Medicine, Wellington Hospital, Wellington, and the \\ National Health Institute, Department of Health, Porirua, New Zealand
}

\begin{abstract}
The role of viral respiratory tract infections in acute exacerbations of asthma was studied prospectively in 31 patients with atopic asthma aged 15-56 years. Patients recorded symptom scores for asthma and peak expiratory flow rate daily for 11 months. In addition, they reported for detailed clinical, functional, and virological study every four weeks and as soon as possible after the onset of worsening asthma or symptoms suggesting a respiratory tract infection. Thirty viral identifications were made, of which $18(60 \%)$ were associated with an exacerbation of asthma. Viral respiratory tract infection was identified in $18(10 \%)$ of the 178 exacerbations of asthma, and in $10(36 \%)$ of the 28 severe exacerbations. The frequency of viral identifications in 16 non-asthmatic, control subjects during the same period was similar. It is concluded that viral respiratory tract infections may cause or be associated with exacerbations of asthma in adults, and that they are an important factor in severe exacerbations.
\end{abstract}

\section{Introduction}

Viral respiratory tract infections are commonly associated with attacks of asthma in children, a viral infection being found in $26-42 \%$ of acute wheezing attacks. ${ }^{1-3}$ The proportion may be even higher when particular respiratory viruses are prevalent, approaching $85 \%$ during some epidemics. ${ }^{3}$ In children under 5 years respiratory syncytial virus and parainfluenza virus are the most common pathogens, ${ }^{3-4}$ whereas in older children rhinovirus and influenza $A$ virus are more prevalent. ${ }^{1256}$ Overall, viral respiratory tract infection is the precipitating factor most frequently associated with acute severe asthma throughout childhood. ${ }^{1-6}$

There is little evidence, however, that viral respiratory tract infections are a common cause of exacerbations in adults with asthma. Previous studies investigating this relationship in adults have been limited by the methods of selecting patients, ${ }^{7}$ viral identification techniques, ${ }^{89}$ diagnostic criteria, ${ }^{10}$ incomplete reporting of exacerbations, ${ }^{8}$ small numbers, ${ }^{11}$ and the absence of comparison with control subjects. We therefore undertook a prospective study

Address for reprint requests: Dr R Beasley, Department of Medicine, Wellington School of Medicine, Wellington Hospital, Wellington 2. New Zealand.

Accepted 5 May 1988 to evaluate the role of viral infections in acute asthma in adults, comparing patients with matched non-asthmatic subjects.

\section{Methods}

PATIENTS AND CONTROL SUBJECTS

We enrolled 31 adults with asthma (initial mean FEV, $76.7 \%$ predicted, range $40-125 \%$ ). All had positive skin test responses to at least three common antigens and two had chronic bronchitis (Medical Research Council definition) in addition. We selected patients from the outpatient clinic if they seemed likely to complete the study and not on the basis of a history of frequent or severe respiratory tract infections. We aimed to keep the background medication of each patient constant throughout the study.

We also studied 16 control subjects (initial mean FEV $101 \%$ predicted, range $82-124 \%$ ) similar to the asthmatic patients in terms of age, sex, smoking history, and presence or absence of children within the family (table 1). The control subjects had no history of asthrna, and the concentration of methacholine causing a $20 \%$ fall in $\mathrm{FEV}_{1}\left(\mathrm{PC}_{20} \mathrm{FEV}_{1}\right)$ was over $8 \mathrm{mg} / \mathrm{ml}$ in all subjects. The study started in January (summer) 1984 and concluded in December 1984. Written informed consent was obtained from all patients and control subjects. The study was approved by the Wellington Hospital Board research ethical committee. 
Table 1 Details of asthmatic patients and non-asthmatic control subjects

\begin{tabular}{|c|c|c|c|c|c|c|c|}
\hline & \multicolumn{4}{|c|}{ Age (y):No } & \multirow{2}{*}{$\begin{array}{l}\text { Sex } \\
(M: F)\end{array}$} & \multirow{2}{*}{$\begin{array}{l}\text { No of current } \\
\text { cigarette } \\
\text { smokers }\end{array}$} & \multirow{2}{*}{$\begin{array}{l}\text { No with } \\
\text { children } \\
\text { in household }\end{array}$} \\
\hline & $15-19$ & $20-29$ & $30-39$ & $40-59$ & & & \\
\hline $\begin{array}{l}\text { Asthmatics }(n=31) \\
\text { Non-asthmatics }(n=16)\end{array}$ & $\begin{array}{l}8 \\
4\end{array}$ & $\begin{array}{l}8 \\
4\end{array}$ & $\begin{array}{l}8 \\
5\end{array}$ & $\begin{array}{l}7 \\
3\end{array}$ & $\begin{array}{r}12: 19 \\
6: 10\end{array}$ & $\begin{array}{l}4 \\
2\end{array}$ & $\begin{array}{r}14 \\
7\end{array}$ \\
\hline
\end{tabular}

\section{CLINICAL PROTOCOL}

The asthmatic patients kept a daily diary of symptoms, bronchodilator use, and peak expiratory flow (PEF). A scoring system was used to grade chest tightness, breathlessness, wheeze, and cough (0-symptoms absent; 1 -mild but not continuous; 2 -moderately severe and present most of day; 3-very severe). Sore throat and sputum production was graded as present or absent. Nasal discharge was scored as present if increased in quantity or abnormally discoloured. PEF was measured in triplicate morning and evening and the mean of the three readings used for analysis.

The patients and control subjects were asked to attend the laboratory as soon as possible after $(a)$ the onset of symptoms suggesting respiratory tract infection or $(b)$ the onset of symptoms of worsening asthma, increased use of bronchodilator aerosol or a substantial drop in PEF; and (c) routinely every four weeks if there had been no "acute" visit during this period.

During the laboratory visit all respiratory symptoms were graded according to the diary symptom scores used for asthma symptoms (0-3--see above). Patients and control subjects were also examined for the presence of occluded nasal airway, mucopurulent nasal discharge or sputum, and pharyngeal inflammation or exudate.

\section{LABORATORY}

Vital capacity (VC) and FEV, were measured with a dry spirometer at each visit, and in the non-asthmatic subjects bronchial reactivity to methacholine was assessed by the technique described by Hargreave. ${ }^{12}$

Nasopharyngeal aspiration for viral studies was performed at every visit. With the patient or subject seated upright, $2 \mathrm{ml}$ of warm, sterile normal saline was instilled from a syringe into one nostril and allowed to run back into the nasopharynx. The secretions were then aspirated into a trap through a soft catheter and the procedure was repeated in the other nostril. The nasopharyngeal aspirate was chilled to $4^{\circ} \mathrm{C}$ and sent within four hours of collection to the virus diagnostic laboratory. Electron microscopy was performed by a non-specific immunoelectron microscopic method using the serum in agar technique followed by negative staining in $2 \%$ phosphotungstic acid..$^{13}$ The specimens were also inoculated into two tissue culture tubes each of $(a)$ primary rhesus monkey kidney (MK) cells, $(b)$ our own strain of human diploid fibroblasts (HEL) $\vec{\omega}$ and $(c)$ the same cell strain but with a different maintenance medium designed to favour rhinovirus isolation (HELRV). The MK and HEL tubes werew incubated in roller drum incubators at $34.5^{\circ}$ and the HELRV tubes at $33^{\circ}$. Detection and identification of the viruses were performed by standard methods. ${ }^{1}$ o Slides were also prepared of the nasopharyngea $L$ aspirate and examined by immunofluorescences microscopy, with antisera against influenza $A$ and $B$ viruses, parainfluenza virus (types 1,2 , and 3 ) respiratory syncytial virus, and adenovirus hexono antigen.

Blood was drawn for serological evaluation ofe antibody titres at the first visit, the routine visit aftebo any acute visit, and at least every six months. Serumb was stored at $-20^{\circ}$ until tested. The complemene fixation test was used to detect antibodies to para influenza virus, adenovirus, and respiratory syncytiaß virus. The haemagglutination inhibition test was usedo to detect the presence of antibody to influenza $A^{a}$ (H3N2 and H1N1) and influenza B. For all serologica tests a rise of at least fourfold in antibody titre was required as evidence of infection; in the case of influenza viruses the titre had to reach at least $1 / 160$.

\section{ANALYSIS}

We diagnosed a clinical respiratory tract infection i i there was an increase in the diary symptom score foos either nasal discharge, sore throat, or sputum produc tion for more than $\mathbf{4 8}$ hours, and also (a) a score for ang individual symptom of infection on the day of the visit of 2 or more or $(b)$ sputum production in excess of an estimated $15 \mathrm{ml} /$ day or $(c)$ the presence of either occluded nasal airway, mucopurulent nasal discharge mucopurulent sputum, or substantial pharyngeaf inflammation or exudate on clinical examination.

An exacerbation of asthma was diagnosed if there was (a) subjective evidence-an increase in the diaryc symptom score for more than one asthma symptom of an increase in bronchodilator use extending over theo preceding 48 hours or asthma symptoms on the day of the visit; and $(b)$ objective evidence - an FEV, less than ${ }^{\text {? }}$ $75 \%$ of the patient's best recorded value during the study or a mean morning or evening PEF, as recorded in the diary, less than $60 \%$ of the usual maximum value. If the FEV , was less than $60 \%$ or the PEF les® than $40 \%$ as defined above, asthma was labelledo 
Table 2 Viruses identified in association with clinical respiratory tract infection (RTI) or asthma

\begin{tabular}{|c|c|c|c|c|c|c|c|c|c|}
\hline \multirow[b]{2}{*}{ Virus } & \multirow[b]{2}{*}{ No } & \multicolumn{4}{|c|}{ Method of viral identification } & \multirow[b]{2}{*}{$R T I$} & \multirow{2}{*}{$\begin{array}{l}\text { No } \\
\text { asthma } \\
\text { or } \\
R T I\end{array}$} & \multirow{2}{*}{$\begin{array}{l}\text { Asthma } \\
\text { exacerbations } \\
\text { (number severe) }\end{array}$} & \multirow{2}{*}{$\begin{array}{l}\text { Mean max } \% \\
\text { reduction in } \\
F E V_{1} \text { from } \\
\text { baseline }\end{array}$} \\
\hline & & IF & $\begin{array}{l}\text { Cell } \\
\text { culture }\end{array}$ & Serology & $E M$ & & & & \\
\hline \multicolumn{10}{|c|}{ Asthmatic patients } \\
\hline $\begin{array}{l}\text { RSV } \\
\text { Rhinovirus } \\
\text { Influenza A } \mathrm{H}_{3} \mathrm{~N}_{2} \\
\text { Influenza B } \\
\text { Parainfluenza } 3 \\
\text { Adenovirus } \\
\text { Herpes simplex } \\
\text { Enterovirus }\end{array}$ & $\begin{array}{r}14 \\
6 \\
1 \\
1 \\
5 \\
1 \\
1 \\
1\end{array}$ & $\begin{array}{r}11 \\
1\end{array}$ & $\begin{array}{l}1 \\
1\end{array}$ & $\begin{array}{l}4 \\
1 \\
1 \\
5 \\
1\end{array}$ & 1 & $\begin{array}{l}9 \\
6 \\
1 \\
1 \\
5 \\
0 \\
1 \\
0\end{array}$ & $\begin{array}{l}2 \\
0 \\
0 \\
0 \\
0 \\
1 \\
0 \\
1\end{array}$ & $\begin{array}{lc}8 & (3) \\
4 & (3) \\
1 & (1) \\
1 & (1) \\
3 & (2) \\
0 & 0 \\
1 & 0 \\
0 & 0\end{array}$ & $\begin{array}{l}29 \\
38 \\
42 \\
78 \\
25 \\
16 \\
14 \\
18\end{array}$ \\
\hline Total & 30 & 12 & 8 & 12 & 1 & 23 & 4 & $18 \quad 10$ & \\
\hline \multicolumn{10}{|c|}{ Non-asthmatic subjects } \\
\hline $\begin{array}{l}\text { RSV } \\
\text { Rhinovirus } \\
\text { Parainfluenza } 3\end{array}$ & $\begin{array}{l}3 \\
5 \\
1\end{array}$ & 3 & 5 & 1 & & $\begin{array}{l}2 \\
4 \\
0\end{array}$ & $\begin{array}{l}1 \\
1 \\
1\end{array}$ & & \\
\hline Total & 9 & 3 & 5 & 1 & 0 & 6 & 3 & & \\
\hline
\end{tabular}

severe.

The $\chi^{2}$ test using Yates's correction was used to determine the significance of differences in the frequency of viral respiratory tract infection (a) during the severe and other exacerbations of asthma, as defined above, and $(b)$ between asthmatic and nonasthmatic subjects.

\section{Results}

The patients and subjects maintained a high degree of interst in the study. Two asthmatic patients withdrew during the first six months of the study but the remaining 29 asthmatic patients and 16 non-asthmatic subjects completed the study. There was no difference in the mean time from onset of symptoms to specimen sampling between exacerbations of asthma in which a viral identification was made ( 2.5 days) and those in which none was made ( 2.3 days), or in the frequency of viral identifications in the asthmatic and the nonasthmatic subjects.

\section{ASTHMATIC PATIENTS}

Patients attended on 69 occasions because of a deterioration in their asthma alone, on 73 occasions for clinical respiratory tract infection alone, on 109 occasions for a combination of the two, and on 161 occasions when they had neither. Each patient made from four to 18 visits. A virus was identified on 30 occasions (table 2). Most (77\%) viral identifications were associated with a clinical respiratory tract infection. The viruses showed no obvious seasonal variation except for parainfluenza virus, which occurred most often in late summer. The frequency of viral identifications was no greater in patients with children in the household nor was the frequency of virus isolation related to the patient's age.

One hundred and seventy eight exacerbations of asthma (28 severe) were recorded. Nine of these were identified retrospectively by review of diary records but the remainder were reported and investigated according to our protocol. Viruses were identified more frequently during severe exacerbations $(10 / 28)$, than in those not identified as severe $(8 / 150 ; p<0.01)$.

\section{NON-ASTHMATIC SUBJECTS}

Nine viral identifications were recorded in the 16 nonasthmatic subjects (table 2). On all occasions the $\mathrm{PC}_{20} \mathrm{FEV}_{1}$ remained greater than $8 \mathrm{mg} / \mathrm{ml}$ in all subjects.

\section{Discussion}

We have shown that viral respiratory tract infections may cause or be associated with exacerbations of asthma in adults with asthma. An exacerbation of asthma occurred on $60 \%$ of the occasions when viruses potentially pathogenic to the respiratory system were identified, a prevalence similar to that found in children. ${ }^{246}$ In children different viruses have been detected at different ages, respiratory syncytial virus and parainfluenza virus III being the most important in infants ${ }^{34}$ and rhinovirus and influenza $A$ virus predominant in older children. ${ }^{1256}$ Our results suggest that in adults with asthma respiratory syncytial virus, parainfluenza virus III, rhinovirus, and influenza virus may all cause exacerbations of asthma, some of which may be severe.

Despite this clear association with asthma, viral respiratory tract infections were identified in only $10 \%$ 
of all the asthma exacerbations documented. This contrasts with the proportions in children, where $26-42 \%$ of asthma attacks may be associated with viral respiratory tract infection..$^{1-3}$ Thus while viruses may have a major role in the provocation of acute asthma in childhood, and indeed have been suggested as an aetiological factor in asthma, ${ }^{1516}$ other factors singly or together must account for most episodes of asthma in adults. Given the recorded increase in atopy with age ${ }^{17}$ and the high prevalence of positive skin test responses in our patients, allergy may be one of these factors.

Of great importance was the frequency with which proved viral infections were associated with severe episodes of asthma, defined as a greater than $40 \%$ fall in $\mathrm{FEV}_{1}$ or $60 \%$ fall in PEF from baseline. Over one third of all such episodes were associated with viral respiratory tract infection. This is consistent with the findings of Huhti et al, who found that $17 \%$ of adults requiring hospital admission for severe asthma had a proved viral infection, although the only method used for viral identification was serology. 9

Only two influenza virus infections were documented in our study, which reflects the few isolations of influenza virus and absence of an epidemic within New Zealand during the study period. ${ }^{18}$ Both influenza infections were associated with severe attacks of asthma, consistent with previous reports for both children and adults. ${ }^{569}$ The recently developed subunit vaccine has been found safe for adults with asthma, ${ }^{19}$ though it is important to show that such vaccination does prevent exacerbations of asthma due to influenza infection.

Previous reports have drawn attention to the importance of family structure as a determinant of the risk of respiratory infection in adults with chronic bronchitis. ${ }^{120} \mathrm{We}$ found no increase in the incidence of viral infection in adults with asthma who had children in the household, thus confirming the findings of Tarlo et $a l,{ }^{10}$ who noted that the frequency of cold symptoms was similar whether there were school age children in the household or not. In contrast to chronic bronchitis therefore, the family structure is not likely to be an important factor in determining the risk of viral infection in patients with asthma.

Non-specific bronchial responsiveness has been shown to increase in non-asthmatic subjects after respiratory infections with respiratory syncytial virus ${ }^{21}$ and influenza $A$ virus ${ }^{22}$ and after presumed viral respiratory infections. ${ }^{23}$ We were unable to detect any non-specific hyperresponsiveness after viral infection in the non-asthmatic subjects, but the number of respiratory syncytial virus infections in this group was small and there were no influenza $\mathbf{A}$ infections. Our study also shows that adults with asthma are no more susceptible to viral respiratory tract infections than
Beasley, Coleman, Hermon, Holst, O'Donnell, Tobias: adults without asthma.

An important problem that must be addressed if any study of this nature is that of study design, and if particular the methods used for viral identification. I I drawing up the study protocol we attempted to overcome the methodological problems present in the previous studies in adults. Subjects reported promptly after the onset of symptoms both of respiratory tract infection and of worsening asthma, and in only $8 \%$ ot symptomatic episodes was nasopharyngeal sampling delayed beyond five days, when the likelihood of virat isolation is reduced. ${ }^{24}$ In our study identification bit viral isolation and by immunofluorescence microso scopy improved the diagnosis of rhinovirus an respiratory syncytial virus infections respectively. ItP particular, this has enabled us to show that respiratory syncytial virus infection is an important cause of respiratory disease leading to exacerbations of asthm\$ in adults as well as children. We did not attemp specifically to isolate coronavirus, which has beew implicated in childhood asthma ${ }^{3}$; but none was detected by direct electron microscopy. We used stricter criteria for serological diagnosis than in mosecto previous studies. ${ }^{7-10}$ Even if more sensitive methods were available for viral identification, we believe thag this would not have altered our conclusions.

In this study viral respiratory tract infection $\frac{}{8}$ occurred no more commonly in adults with asthmळ than in control subjects: but in the asthmatic subjects most infections that were identified were associate with an exacerbation of asthma. Although viral infec 3 tions were associated with only $10 \%$ of episodes of asthma overall, they accounted for over a third of the severe exacerbations.

This work was supported by a grant from the Medica Research Council of New Zealand. We are grateful ti் the patients and subjects for their cooperation. We wish to thank the staff of the virus and mycoplasmå laboratories, National Health Institute, for competen $\overline{2}$ technical assistance, particularly $\mathrm{Mr} \mathrm{N}$ Kuttner (elec오 tron microscopy), Ms M Paterson (cell culture), Ms Millar (viral serology), and Ms J Pearce (mycoplasm serology). Mr Paul Sutthoff, Computer Managern Wellington School of Medicine, programmed the data base.

\section{References}

1 Horn MEC, Brain EA, Gregg I, Inglis JM, Yealland Sf을 Taylor P. Respiratory viral infection and wheezy bron@ chitis in childhood. Thorax 1979;34:23-8.

2 Minor TE, Dick EC, De Meo AN, Ouellette JJ, Cohen $M_{-}^{-}$ Reed CE. Viruses as precipitants of asthmatic attacks in children. JAMA 1974;227:292-8.

3 McIntosh K, Ellis EF, Hoffman LS, Lybass TG, Eller JJ Fulginiti VA. The association of viral and bacteria 
respiratory infections with exacerbations of wheezing in young asthmatic children. J Paediatr 1983;82:578-90.

4 Carlsen KH, Orstavik I. Bronchopulmonary obstruction in children with respiratory virus infections. Eur $J$ Respir Dis 1984;65:92-8.

5 Minor TE, Dick EC, Baker JW, Ouellette JJ, Cohen M, Reed CE. Rhinovirus and influenza type $A$ infections as precipitants of asthma. Am Rev Respir Dis 1976; 113:149-53.

6 Roldaan AC, Masural N. Viral respiratory infections in asthmatic children staying in a mountain resort. Eur $J$ Respir Dis 1982;63:140-50.

7 Hudgel DW, Langston L, Selner JC, McIntosh K. Viral and bacterial infections in adults with chronic asthma. Am Rev Respir Dis 1979;120:393-7.

8 Clarke CW. Relationship of bacterial viral infection to exacerbations of asthma. Thorax 1979;34:344-7.

9 Huhti E, Mokka T, Nikoskelainew J, Halonen P. Association of viral and mycoplasma infections with exacerbations of asthma. Ann Allergy 1974;33:145-9.

10 Tarlo S, Broder I, Spence L. A prospective study of respiratory infection in adult asthmatics and their normal spouses. Clin Allergy 1979;9:293-301.

11 Lambert HP, Stern H. Infective factors in exacerbations of bronchitis and asthma. Br Med J 1972;3:323-7.

12 Hargreave FE, Ryan G, Thomson NC, O'Byrne PM, Latimer K, Juniper EF, Dolovich J. Bronchial responsiveness to histamine or methacholine in asthma; measurement and clinical significance. $J$ Allergy Clin Immunol 1981;68:347-58.

13 Berthiqume L, Alain R, McLaughlin B, Payment P, Trepannier P. Rapid detection of human viruses in faeces by a simple and routine immunoelectronmicroscopy technique. J Gen Virol 1981;55:223-7.

14 Lennette EH, Schmidt NJ, ed. Diagnostic procedures for viral, rickettsial and chlamydial infections. 5th ed. New York: American Public Health Association, 1979.

15 Frick OL. Role of viral infections in asthma and allergy. Clin Rev Allergy 1983;1:5-17.

16 Hall WJ, Hall CB. Bacterial and viral infection in etiology and therapy. In: Weiss FB, Segal MS, Stein M, eds. Bronchial asthma: mechanisms and therapeutics. 2nd ed. Boston: Little, Brown and Co, 1985:435-52.

17 Barbee R A. Allergen skin-test reactivity in a community population sample: correlatin with age, sex and allergen skin test reactivity. J Allergy Clin Immunol 1981;68: 106-11.

18 National Health Laboratory, Kenepuru. Epidemiology report: influenza 1984. NZ Med J 1985;98:196-7.

19 Albazzaz MK, Harvey JE, Grilli EA, Caul ED, Roome AP. Subunit influenza vaccination in adults with asthma: effect on clinical state, airway reactivity and antibody response. $\mathrm{Br}$ Med J 1987;294:1196-7.

20 Eadie MB, Stott EJ, Grist NR. Virological studies in chronic bronchitis. Br Med J 1966;ii:671-3.

21 Hall WJ, Hall CB, Speers DM. Respiratory syncytial virus infection in adults: Clinical, virologic, and serial pulmonary function studies. Ann Intern Med 1978; 88:203-5.

22 Little JW, Hall WJ. Douglas R G. Airway hyperreactivity and peripheral airway dysfunction in influenza $\mathbf{A}$ infection. Am Rev Respir Dis 1978;118:295-303.

23 Empey DW, Laitinen LA, Jacobs L, Gold MW, Nadel JA. Mechanisms of bronchial hyperreactivity in normal subjects after upper respiratory tract infection. Am Rev Respir Dis 1976;113:131-9.

24 Gregg I. The role of viral infection in asthma and bronchitis. In: Proudfoot AT, ed. Symposium on viral diseases. Edinburgh: Royal College of Physicians of Edinburgh, 1975:82-98. (Publication No 46.) 